\title{
PROCESS OF THE SELECTION OF SORGHUM-SUDANK HYBRIDS IN ARID CONDITIONS STEPPE ZONE
}

\author{
Sergey Ivanovich Kapustin ${ }^{1}$, Alexander Borisovich Volodin ${ }^{1}$, Andrey Sergeevich Kapustin ${ }^{2 *}$ \\ ${ }^{1}$ North Caucasus Federal Agricultural Research Center, Nikonov str. 49, Mikhailovsk, \\ Stavropol region, 356241, Russia; \\ ${ }^{2}$ North Caucasus Federal University, Pushkin str. 1, Stavropol, 355017, Russia; \\ "Corresponding Author Andrey Sergeevich Kapustin, e-mail: hpplus@bk.ru;
}

Received December 2019; Accepted March 2020; Published April 2020;

DOI: https://doi.org/10.31407/ijees10.212

\begin{abstract}
Aim of the research is to study the parameters of yield and investigate the quality of green mass, also what is of great importance is determining of the level of true heterosis of the main quantitative traits in new sorghum-sudank hybrids created on a great sterile basis at the North Caucasus Federal Agricultural Research Center. The parental forms of the new hybrids are characterized by high combining ability, a rather great and very significant level of the true heterosis, which makes it possible to obtain hybrids with a high rate of initial growth and post-abortion growth, which have high drought tolerance and give stable green mass yields in the various soil and climatic conditions. The best of them may possess a short sprouting period that includes the appearance of good brooms, which at the Gvardeets was 50 days, Boyarin - 56 days. During mowing periods in these hybrids, in comparison with the average values of the parental forms, the duration of the vegetation period did not extend too much. The Fakel hybrid had a similar period of 65 days. Plant height may also depend on genotypes and is inherited with a high degree of heterosis. On the 30th day of the vegetation, the maximum plant height $(82.0-86.5 \mathrm{~cm})$ was obtained from hybrids Gvardeets, Boyarin, Oda and the standard Navigator. In 2018-2019 in total, for two mowing, the highest yield of green and dry mass was obtained from new sorghum-Sudan hybrids Boyarin (51.18 t/ha and 11.44 t/ha respectively), Fakel (51.42 t/ha and $11.45 \mathrm{t} / \mathrm{ha}$ ), as well as the Gvardeets $(47.53 \mathrm{t} / \mathrm{ha}$ and $11.03 \mathrm{t} / \mathrm{ha})$. These combinations also exceeded the green mass of the Navigator standard by $5.94 \mathrm{t} / \mathrm{ha} ; 6.18 \mathrm{t} / \mathrm{ha}$ and $2.29 \mathrm{t} / \mathrm{ha}$. The level of the true geterosis of the green mass in comparison with the averaged values of the parent forms was marked by $22.6 \mathrm{t} / \mathrm{ha}(78.5 \%)$ for the Fakel hybrid, $16.69 \mathrm{t} / \mathrm{ha}(48.4 \%)$ for Boyarin and $11.80 \mathrm{t} / \mathrm{ha}(33.1 \%)$ of the Gvardeets. Hybrids Gvardeets and Boyarin provided the normal and at the same time the highest content of crude protein (10.38-10.54\%) in absolutely dry matter. The new sorghum-Sudanese hybrid Gvardeets (Zersta 90C x Sputnitsa) was submitted to the state variety test from 2018. Hybrid Boyarin (A-63 x Sputnitsa) is preparing to transfer to some variety testing according to some value facts.
\end{abstract}

Key words: sorghum-sudank hybrid, selection, heterosis level, productivity, green mass. 